Brazilian Journal

of Chemical

ISSN 0104-6632 Engineering

\title{
SUPERCRITICAL CARBON DIOXIDE EXTRACTION OF MACADAMIA (Macadamia integrifolia) NUT OIL: EXPERIMENTS AND MODELING
}

\author{
C. F. Silva ${ }^{1}$, M. F. Mendes ${ }^{2}$, F. L. P. Pessoa ${ }^{3^{*}}$ and E. M. Queiroz ${ }^{3}$ \\ ${ }^{1}$ UFRJ, Ciência de Alimentos, Instituto de Química, Rio de Janeiro - RJ, Brazil. \\ ${ }^{2}$ UFRRJ, Departamento de Engenharia Química, Seropédica - RJ, Brazil. \\ ${ }^{3}$ UFRJ, Departamento de Engenharia Química, Rio de Janeiro - RJ, Brazil. \\ Universidade Federal do Rio de Janeiro, Phone: +(55) (21)2562-7603, \\ Fax: +(55) (21) 2562-7567, Cidade Universitária, Ilha do Fundão, \\ Escola de Química, Bloco E, Sala 207, CEP: 21949-900, \\ Rio de Janeiro - R.J, Brazil. \\ E-mail: pessoa@eq.ufrj.br
}

(Received: February 4, 2007 ; Accepted: November 5, 2007)

\begin{abstract}
Supercritical $\mathrm{CO}_{2}$ extraction of macadamia nut oil was carried out in a flow apparatus at the following operational conditions: pressures of 10,15 and $18 \mathrm{MPa}$; and temperatures of 313 and $353 \mathrm{~K}$; a volumetric flow of $1.64 \times 10^{-7} \mathrm{~m}^{3} \cdot \mathrm{s}^{-1}$ was used for one hour in each experiment. The efficiency of the extraction process showed to be low. The behaviors of the extraction curves were very similar at all temperatures and the best efficiency value was obtained at $10 \mathrm{MPa}$. Chromatographic analysis demonstrated the ability of supercritical $\mathrm{CO}_{2}$ to remove some of the main components of the oil: myristic (C14:0), palmitic (C16:0), oleic (C18:1) and linoleic (C18:2) acids, and that higher pressures favoured the removal of lighter components. The extraction process was represented by a simple model based on Langmuir Isotherm, showing a good data fitting.

Keywords: Macadamia; Supercritical extraction; Extraction modeling.
\end{abstract}

\section{INTRODUCTION}

Macadamia, a native fruitful tree from the rainforest of eastern Australia, has 10 different species already identified, but only two (Macadamia tetraphylla and $M$. integrifolia) are commercially growing in Hawaii, Australia and New Zealand, the greatest world producers. The world-wide expansion of the culture occurred mainly in the decade of 1990; in Brazil, the first tree was planted in the decade of 40's, in the Agronomic Institute (IAC), in Campinas (S.P.), and nowadays the macadamia nut is cultivated in some Brazilian states, such as São Paulo (33\%), Espírito Santo (31\%), Bahia (18\%) and Rio de Janeiro $(10 \%)$; but only $5 \%$ of the production goes to the internal market, as nut, with a small oil production (Sobierajski, et al., 2006). As the value of macadamia in the external market is high, some

*To whom correspondence should be addressed 
companies have decided to export it; however, macadamia still represents a small parcel of the international market of nuts and the world-wide consumption of macadamia is restricted to $2-3 \%$ of the total nuts (Sobierajski, et al., 2006). The industrial use has increased because macadamia can be consumed not only in natura but in processed foods, such as manufactured cakes ( $40 \%$ of worldwide processed), biscuits (35\%), chocolates $(22 \%)$ and ice-creams (3\%) (Stephenson, 2005).

Macadamia nuts have a unique flavor, crunchy texture and high oil content. The kernels are rich in monounsaturated fatty acids (Cavaletto, 1983) and may reduce serum cholesterol when included in a healthy diet (Garg et al., 2003).

Its oil is traditionally obtained using the cold press process which does not allow the posterior use of these fruits. The supercritical oil extraction could be a possible technology to extract the oil, maintaining the nut original structure and obtaining "light nuts" with a low content of fat. Macadamia nuts can be seen in Figure 1.

The extraction using a supercritical fluid, among the different techniques of extraction, is a very important technology due to its characteristics: does not leave residues in the extract and allows choosing a non toxic solvent. Because the residual solvent can be easily removed from the product, the supercritical fluid extraction has wide applications in the food, cosmetic and pharmaceutical industries (Silva et al., 2006). Carbon dioxide $\left(\mathrm{CO}_{2}\right)$ is, in general, the most widely used supercritical solvent due to its advantages like inertness, non-toxicity, nonflammability, non-explosiveness, and availability with high purity at low cost. As the extraction is carried out at a relatively low temperature and under an inert atmosphere, the labile components present in the extract are preserved. Moreover, supercritical fluid technology can provide high solubility, improved mass-transfer rates and increased selectivity with small changes in process temperature and pressure (Brunner, 1992).

The objective of this work was to carry out the macadamia nut oil extraction using a solvent under supercritical conditions, decreasing the content of fat of the nut without alteration of its aroma and palate. Moreover, the pure oil could be used in other industrial sectors.

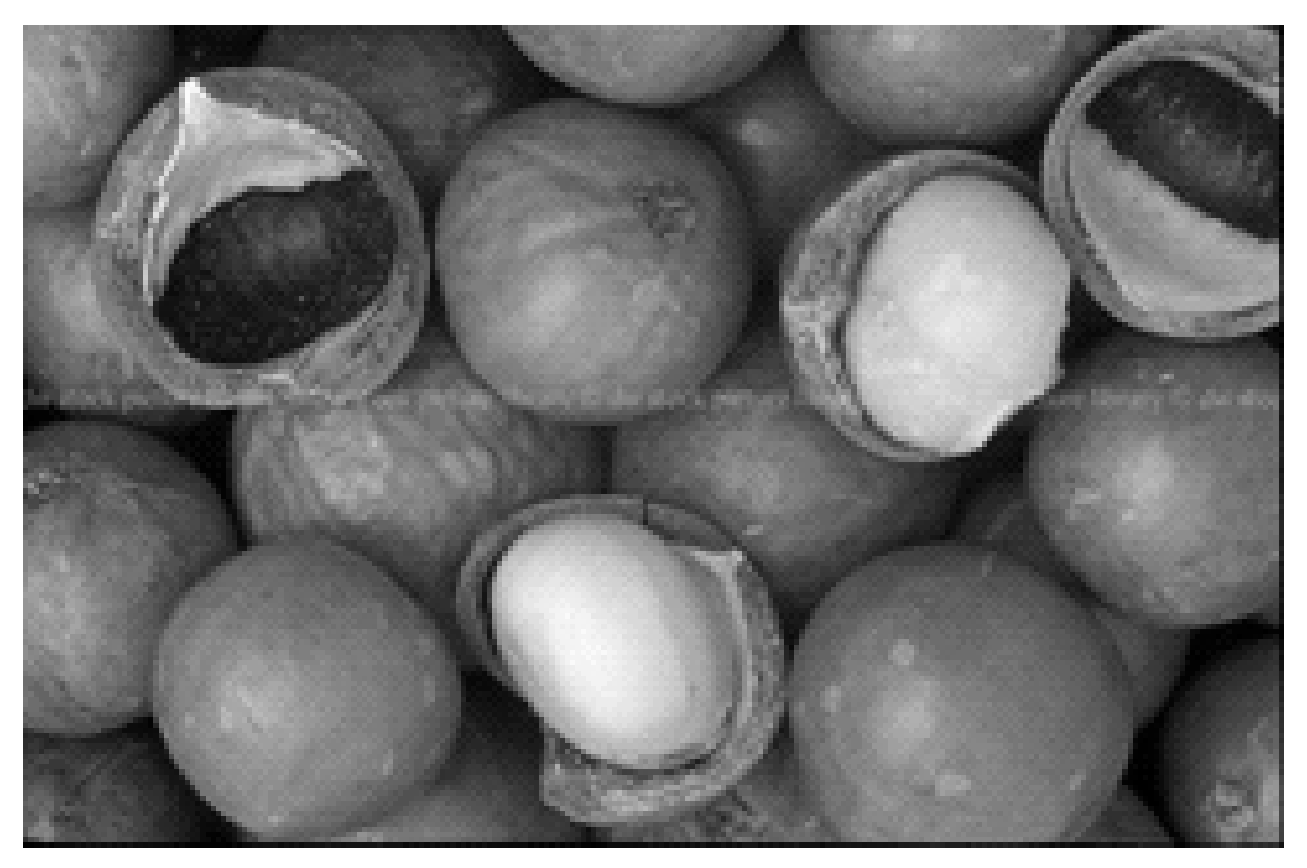

Figure 1: Illustration of Macadamia nuts 
MATERIALS AND METHODS

\section{Materials}

Liquid $\mathrm{CO}_{2}$ (99.9\% pure) was from AGA S.A. (Rio de Janeiro). The experiments were lead using dry macadamia nuts harvested in the Citra Farm (Limeira, São Paulo) in 2006.

\section{Methods}

The oil content was measured by gravimetric analysis. Approximately $12 \mathrm{~g}$ of seeds, previously milled, formed the solid bed characterized by an apparent density of $1600 \mathrm{~kg} \cdot \mathrm{m}^{-3}$ and 0.4250 of porosity.

Analysis of the essential oil components was carried out through gaseous chromatography (GC) in a chromatograph 5890HP series II with flame ionization detector (FID), a HP 5 column $(32 \mathrm{~m}$ length $\mathrm{x} 0.32 \mathrm{~mm}$ of internal diameter $\mathrm{x} 0.25 \mu \mathrm{m}$ of thickness) and connected to an integrator HP 3396 , in the Laboratory of Separation Processes (UFRRJ/IT/ DEQ).

Hydrogen was used as carrier gas with a flow rate of $40 \mathrm{~mL} / \mathrm{min}$ and temperature program of 323 to $443 \mathrm{~K}$, increasing at a rate of $25 \mathrm{~K} / \mathrm{min}$, for 6 minutes. The injector temperature was $523 \mathrm{~K}$ with an injection volume of $1 \mu \mathrm{L}$. The identification of the fatty acids was done comparing their individual retention time and co-injection of standards.

The experimental measurements of the extraction had been performed in an apparatus, built in the Laboratory of Separation and Purification of the PEQ/COPPE, consisting of a high-pressure pump (Thermo Separation Products, Constametric 3200 $\mathrm{P} / \mathrm{F}$ ), a stainless steel 3161 extractor of $4.2 \times 10^{-5} \mathrm{~m}^{3}$, a micrometric valve for sampling, a thermostatic bath $( \pm 0.1 \mathrm{~K}$, Lab-Line Instrument, Inc.; Melrose Park Illinois), a manometer and a rotameter. Liquid carbon dioxide from the supply cylinder passed through a cold bath (approximately about 263K) and then was pumped to the extractor. The flow sheet of the experimental apparatus is shown in Figure 2 and in Silva (2006). The experimental procedure was carried out in a semi-batch way. Initially the extractor was filled with the solid material, previously milled and the solvent $\left(\mathrm{CO}_{2}\right)$ was fed with a $1.64 \times 10^{-7} \mathrm{~m}^{3} \cdot \mathrm{s}^{-1}$ constant outflow. The sampling was done using the micrometric valve, reducing the pressure, and the oily extract was recovered in a previously weighed collector. The operational conditions investigated were 313 and $353 \mathrm{~K}$ temperature and 10,15 and $18 \mathrm{MPa}$, pressure. The maximum process time was $3840 \mathrm{~s}$, at 10 and 15 $\mathrm{MPa}$ and $3660 \mathrm{~s}$, at $18 \mathrm{MPa}$ pressure conditions.

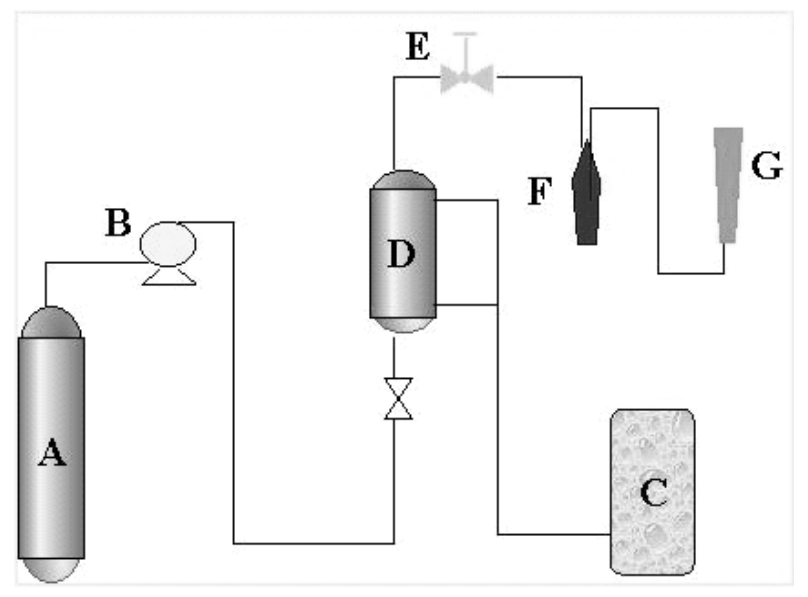
A. Cylinder of $\mathrm{CO}_{2}$
B. High-pressure pump
C. Heating bath
D. Extractor
E. Micrometric valve
F. Sample
G. Flowmeter

Figure 2: Flowchart of experimental apparatus. 


\section{RESULTS AND DISCUSSION}

The oil content of macadamia fruits was approximately $46.01 \%$. It was determined by a method using organic extraction (Marinho et al., 2006); in their study, petroleum ether had been used as solvent extraction in a Soxhlet apparatus for 6 hours.

The process yield was determined using the Equation (1).

yield $\%=\frac{\mathrm{kg} \text { of extract }}{\mathrm{kg} \text { of initial oil content }} \times 100$

The oil mass recovery was very low (about $0.76 \%$ ), when compared to that obtained using an organic solvent. Table 1 shows the yields obtained for each process condition at the end of extraction.

Solubility values for macadamia oil extraction in supercritical $\mathrm{CO}_{2}$ were not found in literature. However, low values were also obtained in the oil extraction of buriti (França et al., 1999). Buriti is an Amazonian native fruit rich in oleic acid (78.73\%) and the solubility values were presented in a range of (2.86-6.82) x $10^{-3}\left(\mathrm{~kg}\right.$ of extract $/ \mathrm{kg}$ of $\left.\mathrm{CO}_{2}\right)$. Although it is well known that solubility data of a single substance obtained from extraction yields of natural matrices are not necessarily the same as solubility data of the same substance in its pure form, it is interesting to show the proximity of this value to that of oleic acid: $8.72 \times 10^{-3}(\mathrm{~kg}$ of oleic acid $/ \mathrm{kg}$ of $\mathrm{CO}_{2}$ ), as determined by Chrastill (1982). These values are much lower than the initial oil content, as confirmed by the experiments. This is a possible justification to the lower yields obtained in this work.

Table 1 presents the extraction behavior as a function of pressure and temperature. This behavior can be better analyzed in Figures 3 and 4. In Figure 3 the extraction curve shows the decrease of process yield, at constant temperature $(313 \mathrm{~K})$, as pressure increases and Figure 4 shows the increase in oil recovery when temperature is lowered at constant pressure of $10 \mathrm{MPa}$. This is an expected behavior due to the fact that when the temperature increases, the solvent density decreases and the extracted mass also decreases.

The chromatographic analysis showed that supercritical $\mathrm{CO}_{2}$ was able to remove some of the main components of the oil: myristic (C14:0), palmitic (C16:0), oleic (C18:1) and linoleic acids (C18:2), demonstrating that an increase of pressure better favored the removal of lighter components: C14:0 and C16:0, than the heavier, C18:1 and C18:2. Figure 5 shows these results for $313 \mathrm{~K}$ at 10 and 15 MPa compared to the results obtained by Silva (2003), using Soxhlet extraction during 6 hours.

It can be seen that the supercritical carbon dioxide could selectively extract some acids like myristic, palmitic, oleic and linoleic.

Table 1: Yield (\%) for each condition at maximum extraction time

\begin{tabular}{|c|c|c|}
\hline \multicolumn{2}{|c|}{ T (K) } & $\mathbf{3 4 3}$ \\
\hline P(MPa) & $\mathbf{3 1 3}$ & yield \% \\
\hline 10 & yield \% & 0,60 \\
15 & 0,76 & 0,39 \\
18 & 0,68 & 0,25 \\
\hline
\end{tabular}

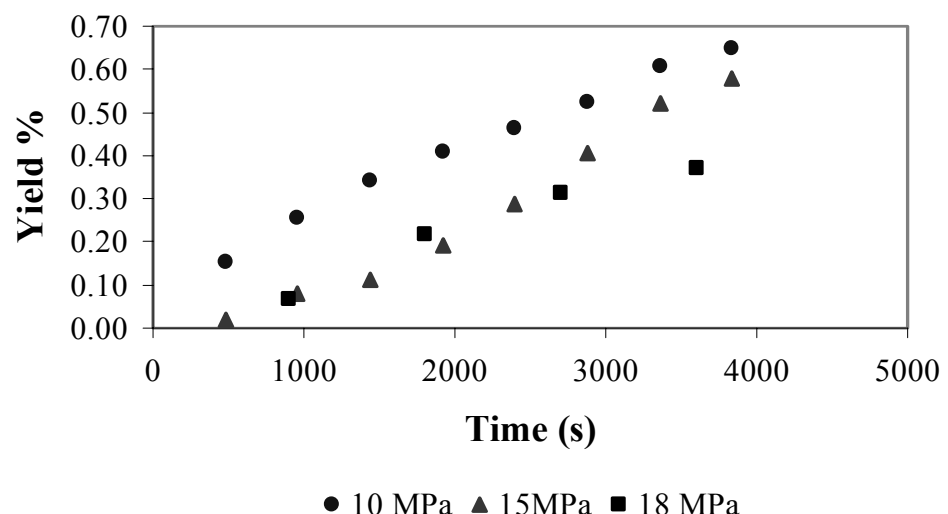

Figure 3: Extraction curve at $313 \mathrm{~K}$ and 10, 15 and $18 \mathrm{MPa}$ 


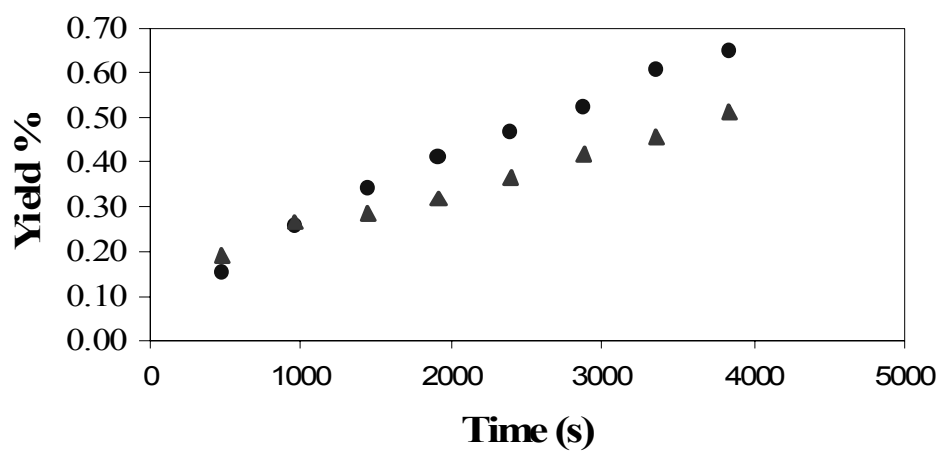

- $313 \mathrm{~K} \triangle 353 \mathrm{~K}$

Figure 4: Extraction curve at $10 \mathrm{MPa}$ and 313 and $353 \mathrm{~K}$

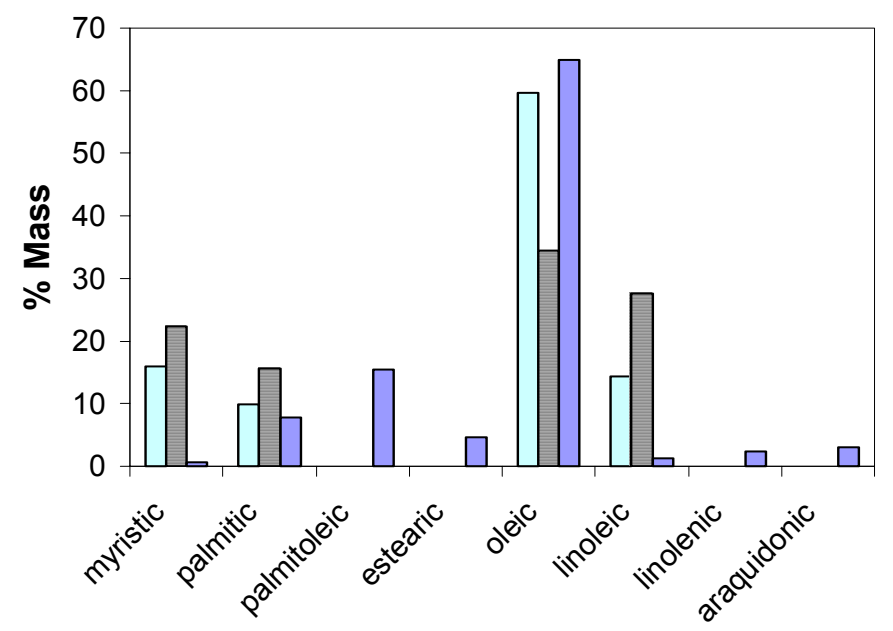

$\square 313 \mathrm{~K} 10 \mathrm{MPa} \square 313 \mathrm{~K} 15 \mathrm{MPa} \square$ soxhlet

Figure 5: Chromatographic analyses results for $313 \mathrm{~K}$ (10 and $15 \mathrm{MPa})$ extracts

\section{MATHEMATICAL MODELING}

A simple model was applied to fit the extraction curves of macadamia oil. The extraction process was studied based on the similarities between the extraction curves and the isotherm of Langmuir, as previously done by Naik and Lentz (1988) and also applied by some other groups of researchers with satisfactory results. As observed by Esquível et al. (1999), this empirical model does not consider interactions between the solute and the solid matrix.

The model is represented by Equation (2) that has only two parameters of adjustment: $e_{\text {lim }}$ and $\mathrm{b}$. The value found for $e$ (yield) is equivalent to the ratio of recovered mass of oil on time $t(s)$ to the initial mass of solute-free feed $(\mathrm{kg}$ of oil/ $\mathrm{kg}$ of solute-free feed) and $e_{\lim }$ is the $e$ value for infinite extraction time or the maximum amount of solute recovered; while the ratio $e_{\mathrm{lim}} / \mathrm{b}$ corresponds to the initial slope of the extraction yield curve versus time.

$$
\mathrm{e}=\mathrm{e}_{\lim }\left(\frac{\mathrm{t}}{\mathrm{b}+\mathrm{t}}\right)
$$

Yields (\%) and deviation (DV \%) were calculated using Equations 3 and 4, respectively, in which: solutefree mass means the difference between the sample mass and the extract mass; exp. means experimental and model means estimated through the model.

Yield $\%=100 \frac{\text { extracted solute mass }}{\text { solute }- \text { free mass }}$

$\mathrm{DV} \%=\frac{100}{\mathrm{~N}_{\exp }}$

$\sum\left|\frac{(\text { exp.yield } \%)-(\bmod e l \quad \text { yield } \%)}{(\exp . \text { yield } \%)}\right|$ 
The empirical model, in the majority of the conditions studied, was able to adjust the results as function of time; the average deviation varied between 3.23 and $40.94 \%$, as shown in Table 2 .

With the exception of the condition of $313 \mathrm{~K}$ and $18 \mathrm{MPa}, e_{\text {lim }}$ parameter presented very low values, but $b$ parameter presented high values and great variation indicating its dependency on the process conditions. Since this model is based on Langmuir isotherm it should represent well only the initial period of the extraction process, which is associated to the dessorption stage and a convective mechanism. It is important to remember that extraction processes occur in three stages: the first one is controlled by a convective mechanism, the third and last controlled by the diffusion mechanism and the second being a transition stage, as suggested by Sovová (1994).

The large value of DV\% reached at $313 \mathrm{~K}$ and $15 \mathrm{MPa}$ is associated to the variation of fluid flow that occurs because of the micrometric valve. This is something that can occur in experimental apparatus in which micrometric valves are used due to the Joule-Thompson effect. Figure 6 shows experimental and calculated yield $\%$ as function of time.

Table 2: Empirical model parameters and deviation (DV \%)

\begin{tabular}{|c|c|c|c|}
\hline P (MPa) & $\mathbf{e}_{\text {lim }}$ & b & DV\% \\
\hline \multicolumn{4}{|c|}{$313 \mathrm{~K}$} \\
\hline 10 & 0.01168 & 3383 & 3.23 \\
\hline 15 & 0.04059 & 55000 & 40.94 \\
\hline 18 & 514927 & $5.03 \mathrm{E}+11$ & 15.77 \\
\hline \multicolumn{4}{|c|}{$353 \mathrm{~K}$} \\
\hline 10 & 0.0076 & 2000 & 11.05 \\
\hline 15 & 0.0162 & 16000 & 6.48 \\
\hline 18 & 0.0033 & 1800 & 6.70 \\
\hline
\end{tabular}

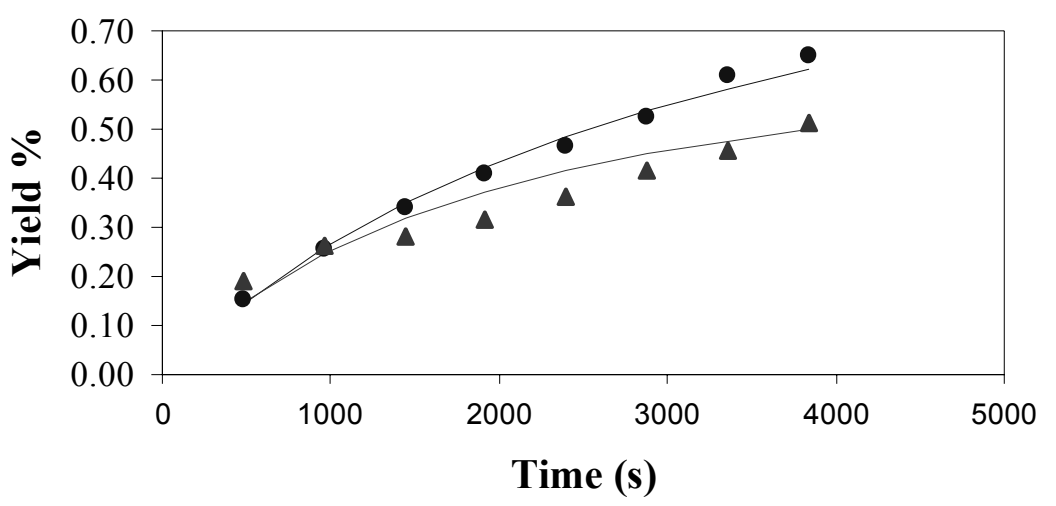

- $313 \mathrm{~K}-$ model $\triangle 353 \mathrm{~K}-$ model

Figure 6: Extraction curves at $10 \mathrm{MPa}$ and 313 and $353 \mathrm{~K}$ (experimental and model)

\section{CONCLUSIONS}

The yields of supercritical $\mathrm{CO}_{2}$ extraction of macadamia oil were low (less than 1\%) and the best result was obtained at $313 \mathrm{~K}$ and $10 \mathrm{MPa}$, the lower operational conditions. These operational conditions imply a process with lower energy costs and less solvent amount, which is important in industrial scale.

Chromatographic analyses showed that supercritical $\mathrm{CO}_{2}$ was able to remove some of the main components of the oil and that higher pressures remove larger amount of lighter components.

The empirical model was able to represent the initial stage of the studied extraction process, that is controlled by the convection mechanism and the only one observed in this study due the short time extraction (1 hour). The parameters estimated by the model could be used to estimate the necessary time to extract the total oil present in the nut. However, because of the low solubility of the oil in $\mathrm{CO}_{2}$ it can be concluded that the calculated time could be too long. 


\section{NOMENCLATURE}

\begin{tabular}{|c|c|}
\hline 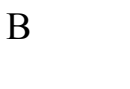 & of empirical \\
\hline V\% & deviation \\
\hline & $\begin{array}{l}\mathrm{kg} \text { of oil } / \mathrm{kg} \text { of recovery } \\
\text { mass of oil on time } \mathrm{t}\end{array}$ \\
\hline$e_{\text {lim }} / b$ & $\begin{array}{l}\text { initial slope of extraction } \\
\text { yield }\end{array}$ \\
\hline $\begin{array}{l}\text { exp. } \\
\text { yield\% }\end{array}$ & experimental yield \\
\hline $\begin{array}{l}\text { model } \\
\text { vield } \%\end{array}$ & $\begin{array}{l}\text { yield estimated through th } \\
\text { model }\end{array}$ \\
\hline $\mathrm{N}_{\exp }$ & experimental point numb \\
\hline & press \\
\hline & temperature \\
\hline & time \\
\hline & $\begin{array}{l}=(\mathrm{kg} \text { of extract } / \mathrm{k} \\
\text { oil content }) \times 100\end{array}$ \\
\hline
\end{tabular}

\section{REFERENCES}

Brunner, G., Malchow, Th., Stürken, K. and Gottschau, Th., Separation of tocopherols from deodorizer condensates by countercurrent extraction with carbon dioxide, The Journal of Supercritical Fluids, 4, 72 (1992).

Cavaletto, C. G., Macadamia nuts. In H. T. Chan (Ed.), Handbook of tropical foods, New York: Marcel Dekker, Inc. 361 (1983) appud Wall, M. M. and Gentry, T. S. Carbohydrate composition and color development during drying and roasting of macadamia nuts (Macadamia integrifolia), LWT- Food Science And Technology, IN PRESS (2006).

Chrastil, J., Solubility of solids and liquids in supercritical gases, Journal of Physical Chemistry, 86, 3016 (1982).

Esquível, M. M., Bernardo-Gil, M. G. and King, M. B., Mathematical models for supercritical extraction of olive husk oil, The Journal of Supercritical Fluids, 16, 43 (1999).

França, L. F., Reber, G., Meireles, M. A. A., Machado, N. T., Brunner, G. Supercritical extraction of carotenoids and lipids from buriti (Mauritia flexuosa), a fruit from the Amazon region, The Journal of Supercritical Fluids, 14, 247 ( 1999).

Garg, M. L., Blake, R. J. and Wills, R., Macadamia nut consumption lowers plasma total and LDL cholesterol levels in hypercholesterolemic men, Journal of Nutrition, 133, 1060 (2003)appud Wall, M. M. and Gentry, T. S., Carbohydrate composition and color development during drying and roasting of macadamia nuts (Macadamia integrifolia), LWT- Food Science And Technology, IN PRESS (2006).

Marinho, P.Q., Mendes, M.F. and Coelho, G.L.V., Extração do óleo do fruto da macadâmia pelos processos de hidrodestilação, soxhlet e infusão. In: XV Jornada de iniciação científica da UFRRJ, Rio de Janeiro (2006), in CD-ROM.

Naik, S. N. and Lentz, H., Extraction of perfumes and flavours from plant materials with liquid carbon dioxide under liquid-vapour equilibrium conditions, Fluid Phase Equilibria, 49, 115 (1988).

Silva, C. F., Mendes, M. F., Pessoa, F. L. P., Queiroz, E. M. and Coelho, G. L. V., An experimental study of supercritical $\mathrm{CO}_{2}$ extraction of rose pepper (Schinus molle) and macadamia nuts (Macadamia integrifolia) oils, Proceedings of VII Iberoamerican Conference on Phase Equilibria and Fluid, Mexic (2006), in CDROM.

Silva, C.F. Modelos matemáticos para o processo de transporte de massa na extração de produtos naturais de matrizes sólidas utilizando $\mathrm{CO}_{2}$ supercrítico: estudo experimental e teórico, p.103, Dissertação (Mestrado em Ciência de Alimentos) - IQ/UFRJ, Universidade Federal do Rio de Janeiro, Rio de Janeiro (2006).

Silva, M. G. Macadâmia nacional: tocoferóis e caracterização físico-química, p.89, Dissertação (Mestrado em Ciência de Alimentos) Universidade Estadual de Campinas, São Paulo (2003).

Sobierajski, G. R., Francisco, V. L. F. S., Rocha, P.,Ghilardi, A. A. and Maia, M. L. Noz macadâmia: produção, mercado e situação no Estado de São Paulo. Informações Econômicas, 36, 25 (2006).

Sovová, H. Rate of the vegetable oil extraction with supercritical $\mathrm{CO}_{2}-\mathrm{I}$. Modeling of extraction curves, Chemical Engineering Science, 49, 409 (1994).

Stephenson, R. Macadamia: domestication and commercialization, Chronica Horticultura, 45, 11 (2005). 